\title{
駐車実態調查方式の研究* \\ STUDY ON THE METHODS OF PARKING SURVEY
}

\author{
毛 利 正 光** \\ By Masamitsu Mōri
}

要旨本文は従来諸外国ならびにわが国で実施 されてきた駐車実態の調査方式について比較検討し，そ の利害得失を明らかにするとともに，駐車場の計画に当 って必要な基礎事項とその意義を明確にし，駐車実態調 查の新しい一つの方式を提案したもので，この方式によ った場合の調査結果の精度扣よび結果の補正の方法につ いて述べたものである。

\section{1. まえがき}

最近の急激な自動車交通の増加にともなう都市交通の 混雑渋滞は，いまや街路計画に抜本的手術を施さねばと ろてい救いがたい状況となってきた。しかるに街路の新 設・幅員の增大は用地・財政上の観点から, きわめて至 難の事業であると考えなければならない。しかして都市 活動の能率・利便, 交通の安全・緩和を計るために都市 そ扣ける駐車の問題は，今ただちにその解決を計らなけ ればならない焦眉の急にある。その対策上の根幹は路外 駐車場の建設にあり, 駐車場整備地区の指定にともなう 駐車場の指定・建設に当っては, 限られた場所が能率よ くもっとも有効に利用されるように, 駐車の実態, 駐車 の習性の科学的調査にもとついて, 問題解決のためのも っとも好をしい方策が樹てられなければならない。駐車 現象はきわめて複雑でその地域的性格を究明する必要が あり，かなり大規模な奏態調査が行なわれなければなら ない。これには多大の経費を必要とする。わが国大都市 に抳いても，まだ駐車に関する資料はきわめて乏しい状 態にある。このためなるべく広範囲にわたる調査を行な い, 駐車に関する概沅を把握して, 問題解決上の基本的 方針が確立されなければならない。

ここに提案した駐車実態調査方式は, きわめて容易に 実用に供しろるものと思う。ここに従来渚外国ならびに わが国に括いて実施せられてきた各調査方式について検 討するとともに, 改めて計画に必要な基礎的事項につい て再考し, 最後に実測例について述べることとした。

\section{2. 駐車に関する基本的問題}

最近の急激なる自動車交通の増加にともない, 大都市 に打ける駐車の問題は, 都市活動の能率化, 利便と合わ

* 一部第 4 回日本道路会議論文集 $\cdot$ 土木学会第 13 回年次学 術講演会で発表

** 正員 工博 名大教授兼大阪市大講師 工学部土木教室
せて交通の安全, 緩和を計るための種々なる問題を提起 しているが, 一体, 道路は人や物を輸送するためのもの であって, そこに駐車することは与えられた特典である と考えるべきことであって, 権利ではない。交通量の増 加につれて, その道路を最大限に利用できるようにする ことがもっとも重要なことである。したがって，その利 用効果をもっとも大ならしめるためには, 駐車の制限や 禁止が必要で, これらのことは交通安全のため怔要 とされることである。

それで交通容量を増加するために考えられる第一のこ とは, 最大交通時の間, 最大容量の必要とされる街路の 重交通側の駐車の制限や禁止をすることである。

つぎに, 安全, 便宜括よび街路幅員の効果的利用とい ろ見地からすると, 路上駐車の形式としては, 平行駐車 (Parallel Curb Parking) がもっとも障害が少ない。斜 角駐車 (Angle Curb Parking) 柱同一縁石長について は平行駐車の場合より多くの車を収容しろるが, 二, 三 の不利な点もある。すなわち, 平行駐車の場合より一首

図-1

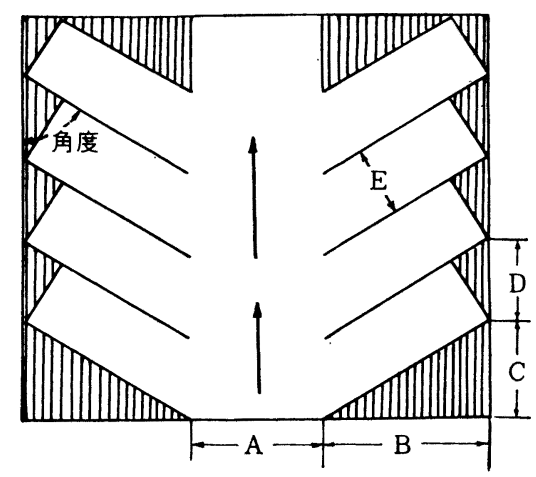

\begin{tabular}{c|c|c|c|c|c|c}
\hline 騂車 & $\begin{array}{c}\text { 1台当りの } \\
\text { 面 }\end{array}$ & $\mathrm{A}$ & $\mathrm{B}$ & $\mathrm{C}$ & $\mathrm{D}$ & $\mathrm{E}$ \\
\hline 平行 & $\begin{array}{c}297 \mathrm{ft}^{2} \\
\left(27.59 \mathrm{~m}^{2}\right)\end{array}$ & $\begin{array}{c}11^{\prime} \\
(3.36 \mathrm{~m})\end{array}$ & $\begin{array}{c}8^{\prime} \\
(2.44 \mathrm{~m})\end{array}$ & $\begin{array}{c}22^{\prime} \\
(6.71 \mathrm{~m})\end{array}$ & - & $\begin{array}{c}8^{\prime} \\
(2.44 \mathrm{~m})\end{array}$ \\
\hline $35^{\circ}$ & $\begin{array}{c}335 \mathrm{ft}^{2} \\
\left(31.12 \mathrm{~m}^{2}\right)\end{array}$ & $\begin{array}{c}11.5^{\prime} \\
(3.51 \mathrm{~m})\end{array}$ & $\begin{array}{c}15^{\prime} \\
(4.58 \mathrm{~m})\end{array}$ & $\begin{array}{c}21.4^{\prime} \\
(6.53 \mathrm{~m})\end{array}$ & $\begin{array}{c}14^{\prime} \\
(4.27 \mathrm{~m})\end{array}$ & $\begin{array}{c}8^{\prime} \\
(2.44 \mathrm{~m})\end{array}$ \\
\hline $45^{\circ}$ & $\begin{array}{c}299 \mathrm{ft}^{2} \\
\left(27.78 \mathrm{~m}^{2}\right)\end{array}$ & $\begin{array}{c}12^{\prime} \\
(3.66 \mathrm{~m})\end{array}$ & $\begin{array}{c}17^{\prime} \\
(5.19 \mathrm{~m})\end{array}$ & $\begin{array}{c}17^{\prime} \\
(5.19 \mathrm{~m})\end{array}$ & $\begin{array}{c}11.3^{\prime} \\
(3.45 \mathrm{~m})\end{array}$ & $\begin{array}{c}8^{\prime} \\
(2.44 \mathrm{~m})\end{array}$ \\
\hline $60^{\circ}$ & $\begin{array}{c}276 \mathrm{ft}^{2} \\
\left(25.64 \mathrm{~m}^{2}\right)\end{array}$ & $\begin{array}{c}18^{\prime} \\
(5.49 \mathrm{~m})\end{array}$ & $\begin{array}{c}18^{\prime} \\
(5.49 \mathrm{~m})\end{array}$ & $\begin{array}{c}10.4^{\prime} \\
(3.17 \mathrm{~m})\end{array}$ & $\begin{array}{c}9.2^{\prime} \\
(2.81 \mathrm{~m})\end{array}$ & $\begin{array}{c}8^{\prime} \\
(2.44 \mathrm{~m})\end{array}$ \\
\hline $90^{\circ}$ & $\begin{array}{c}228 \mathrm{ft}^{2} \\
\left(21.18 \mathrm{~m}^{2}\right)\end{array}$ & $\begin{array}{c}23^{\prime} \\
(7.20 \mathrm{~m})\end{array}$ & $\begin{array}{c}17^{\prime} \\
(5.19 \mathrm{~m})\end{array}$ & - & $8^{\prime}$ & $8^{\prime}$ \\
$(2.44 \mathrm{~m})$ & $(2.44 \mathrm{~m})$ \\
\hline
\end{tabular}




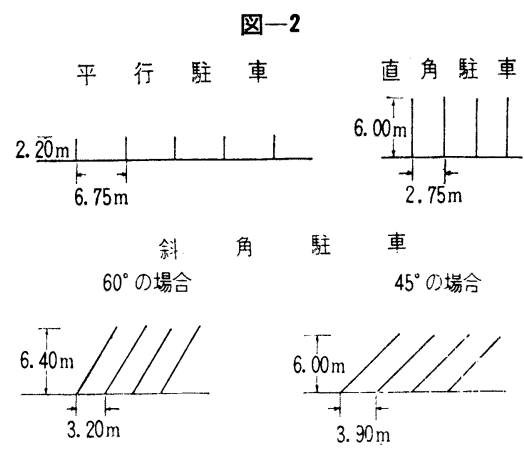

街路容量を減じ，駐車場所への出入の際の見通しが覀 く, 上り危険が多い。また出入に際して, 隣接走行車線 の 1 車線あるいはそれ以上の交通車雨に刘して妨害を与 えたり，抵触したりする。またつぎに駐車場の整備・計

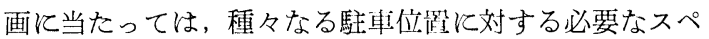
一スを明らか炕する必要がある。い本車两 1 台当り必要 とされるスペースについて米国に批るる例を示すと, 図 一1 のようである。またわが国衹いて，技術的な基準 として考光られているるのを示すと，図一2 のごとくで ある。これらの 図一1,2 に示す做は駐車スペースの配 置計画汇当たって参考となる值である。

つぎに問題を将来について考觉るならば, 都市が成長 発展するにつれて, 建物の改善とか, 交通の変動に関連 して, サービスのためとか交通規制に上り, 路側スペー スはますます制約・制限をうけることとなり，一方路側 スペースの物理的拡がりには限度があるから, 都心業務 地区の路上駐車可能スペースは減ずることになる。した がって, 路側スペースの減少と自動車利用の增大を補償 するためには, 当然路外駐車施設を設備しなければなら ないことになってくる。

世界の大都市はこのよろな状況下にあるので，駐車と 貨客の積降しの問題に対処するために設けられなければ ならない路上駐車スペースと路外駐車スペースの容量と 位置を決定する必要があり，またこれらの施設の将来の 必要量についても考虑することが肝要である。

\section{3. 駐車場計画に必要な調查事項}

計画に当たって必要な調查すべき一般的事項はつぎ 6 ようである。

（1）駐車台数（時刻別，車種別，駐車時間別）

（2）既設の駐車施設の利用状況（駐車時間, 利用目 的などをふくさ）

(3) 駐車形式 (路側一平行, 直行, 斜角, 2 列など, ガレージ, 画地, その他)

(4) 平均駐車時間

（5）駐車地と目的地との関係 (位置, 距離, 歩行時 間など)

（6）駐車飞よる占用状況, 集 中の 度 合 (平均占用
率，回転率，駐車集中指数)

（7）駐車施設招よび貨客の積降し施設に対する要求 度（その緊急度扣よび将来の推定）

（8）新設駐車場の位置と計画（将来施設の希望的位 置などをふくさり

（9）駐車扔よび乗客の乗降の制限，禁止の状況

（10）駐車場がある地域の交通流飞扔よぼす影響

(11) 財政的観点からの調查

以上は駐車場の訐画整備飞当たって必要な一般的調查 事項であるが，駐車場の計画設計に当たって技術的に必 要とせられる基礎的事項について述べると

(a) 時刻別駐車台数と駐車集中の度合

（b） 駐車の場所的特性（駐車時間別台数招よび平均 駐車時閂)

(c) 時刻別駐車の発生状況（駐車需要）

であって, これらの事項は観測によりその実態を把握す ることができ, 駐車場の容量, 形式を決めるために必要 な基本的事項であって, これはまた駐車場の運営管理上 にも重要となる事項である。

つぎに計画に必要な一般的事項に関する用語について 説明するとつぎのよろである。

(1) 実駐車台数：調査時間中に調查区域駐車してい た自動車の総台数。

(2) 観測延台数 : 各調查時刻飞観測された駐車台数の 総和である。したがって1台の車が何回にる観測される ことがある。

(3) 許容台数 : 駐車容量ともいい, 調查区域に同時に 合法的に駐車できる台数である。

したがって路上駐車の許容台数は

路上の駐車汻容延屒 自動車 1 台当りの駐車スペースの長さ で表わされる。

(4) 駐車需要量：駐車汶対する要求度の大きさを表わ すもので, 一般とは, その量を示す単位は明確にされて いないようであるが，通常 (1) の実駐車台数で示されて いる。いまここでは需要量の大小をより敩密に表わする のとして（台一侍）なる単位を用いることとすると， あ る調查時間中の 駐車需要量は $\Sigma$ (駐車時間 $\times$ 台数) を 単位台一時で表わしたものとなる。

(5) 平均回転率：調査時間中に区域内の駐車 1 区画当 たり平均何回出入があったかを示す数值で，

\section{実駐車台数 \\ 許容台数}

として算出される。

入車台数が多いほど，また 1 台の駐車時間が短いほ ど，回転率は大きくなる。

(6) 平均占用率：駐車に上る占用時間の程度を示す比 率であり, 


\section{$\frac{\left.\sum \text { (駐車時間 } \times \text { 台数 }\right)}{\text { 調査時間 } \times \text { 許容台数 }}$}

として算出される。

回転率がいかに小さくても, 個々の車の駐車時間が長 ければ，占用率は大きくなる。駐車施設や路上駐車場の 利用状態はこの值によって示される。したがって駐車施 設の容量を決めるためには駐車時間の測定が必要となっ てくる。

(7) 平均駐車時間

$$
\frac{\sum \text { 各自動車の駐車時間 }}{\text { 実駐車台数 }}
$$

で表わされるが, 調査に当たって後述の断続式観測を行 なった場合には，個々の車の駐車時間はわからないが， あとで述べるよろな調査方式によって, 適当な補正をし て求めることができる。

（8) 駐車（集中）指数：駐車場所の混雑の度合を示す 值で, ある時刻の駐車台数を許容台数で割った值で表わ される。

(9) 駐車と停車の区別：調査に当たって駐車，停車の いずれと判定すべきかと迷うことがあるが，駐車とは客 待ち, 荷待ち, 貨物の積降し, 故障などのため車を継続 的に停止させることをいい, したがって,タクシ一の発 着, バスの乗降などは駐車調査の対象とならないが，こ れらについても一般的調查事項のに示したごとく，その 実態は知って扔くことが必要である。な招従来法的には 短時間の車の停止飞扔いても運転者が車を離れた場合に は駐車とみなされていたが, 新道路交通法によれば, 短 時間（5分以内）であれば運転者がその車両を離れて も，ただちに運転に従事することができる状態にあると きは駐車とみなされない。

(10) 駐車禁止区域：道路交通法に上れば，一般汇駐車 が禁止されている場所としては，

1) 交差点, 横断歩道, 踏切または軌道敷内

2）交差点の側端または道路の曲り角から (5 m) 以内

3）安全地帯の左側招よびその両端から（10m）以内

4）軌道車の停留場または乗合自動車の停 留所から $(10 \mathrm{~m})$ 以内

5）鉄道または軌道の踏切から（10 m) 以内

6) 消火栓・消防用機械器具の置場から (5 m) 以内

7) 道路工事区域の側端から（5 m) 以内

8）道路飞接する自動車用出入口から（3 m) 以内

9) 火災報知器加 (1 in) 以内

10）消防用防火水槽の側端，吸水口・吸管投入孔また はこれらの道路に接する出入口から (5 m) 以内

11） その他公安委員会の指定する場所 また駐車場法による駐車場整備地区に指定され た地域に执いては駐車場法によらなければならな w。

\section{4. 駐車実態の調查方法とその比較検討}

駐車状況調查の方法には，一般に人力（徒少）により 記帳する方法と写真掫影, 自動車上から記録して行く方 法が考光られるが, 要求される钼測の精度と経費, 時間 などにより決められるが，扣上そつぎのようになる。

\section{(1) 観測による方法}

駐車台数の算定を主良とする调査方法であり,つぎの ような方法がある。

a) 断経式调查

(1) プレート断続式：受持ち区域に駐車のために出入 する自動車の登録番号をある一定時間ごとと調查表 飞記入する方法。

(2) ノンプレート断続式：受持ち区域に駐車のために 出入する自動車の台数をある一定侍間ごとに調查表 に記入する方法。

b) 連続式调查

(3) プレート連続式：(1) の調查を連続的飞行なう方 法。

(4) ノンプレート連続式：(2) の調查を連続的に行な 万方法。

な括プレート断続式と同様の操作を写真撮影とより, また自動車上から祀録していく方法などもある。

\section{(2) 質問による方法}

駐車場所と目的地との関係を知るための調查方法であ るが, 車種, 駐車時間, 駐車場所の利用頻度などに関す る情報も得られる。

a) 面接式出発地, 目的地, 駐車目的, 駐車 (見 込）時間，利用頻度などを運転手飞直接質問して，記録 する方法。

b) カード式駐車場の入口, 路側・駐車地などで 調査カードを手渡して, 上記質問の回答を記入させる方 法。

c)八ガキ式 面接の質問応じてくれる暇のない 人に, あらかじめ印刷してあるハガキにカード式同様の 質問をかき,これに記入して折这し郵送してもらう方法。 以上いろいろな方法があるが, これらの各種調査方法

表一1 調查方法別調查可能事項一筧

\begin{tabular}{|c|c|c|c|c|c|c|}
\hline 方 法 & $\begin{array}{l}\text { 面 } \\
\text { 接 } \\
\text { 力 } \\
\text { I }\end{array}$ & $\begin{array}{l}\text { M } \\
\text { カ } \\
\text { キ }\end{array}$ & $\begin{array}{l}\text { プ継 } \\
\text { V続 } \\
! \\
r\end{array}$ & $\begin{array}{l}\text { ノ } \\
\text { ント } \\
\text { プ 継 } \\
\text { レ続 }\end{array}$ & $\begin{array}{l}\text { プ連 } \\
\text { レ続 } \\
! \\
\text { ト }\end{array}$ & $\begin{array}{l}\text { ノ1 } \\
\text { ント } \\
\text { プ連 } \\
\text { レ続 }\end{array}$ \\
\hline 時刻別駐車台数 & $x$ & $x$ & $\triangle$ & $\triangle$ & 0 & 0 \\
\hline 最大駐 車 台 数 & $x$ & $x$ & $\triangle$ & $x$ & 0 & 0 \\
\hline 車種別駐車台 数 & $\triangle$ & $\triangle$ & $\triangle$ & $\triangle$ & 0 & 0 \\
\hline 駐車時間別駐車台数 & $\triangle$ & $\triangle$ & $x$ & $x$ & 0 & $\times$ \\
\hline 駐 車 形 式 & 0 & $\triangle$ & 0 & 0 & 0 & 0 \\
\hline 平均 駐 車 時 間 & $\triangle$ & $\triangle$ & $x$ & $\times$ & $\mathrm{O}$ & $\mathrm{O}$ \\
\hline 最 大駐 車 時 間 & $\triangle$ & $\triangle$ & $x$ & $x$ & $\mathrm{O}$ & $x$ \\
\hline 平均占用率および回転率 & $\triangle$ & $\triangle$ & $\triangle$ & $\triangle$ & O & $\triangle$ \\
\hline 駐車場所と目的地の関係 & 0 & $\triangle$ & $x$ & $x$ & $x$ & $x$ \\
\hline
\end{tabular}

$\bigcirc$ 調查可能・正確 $\Delta$ 調查可能・不正確 $\times$ 調查不可能 
別調査可能事項を示すと 表一1 のようである。

これらの各種調查方法の得失について検討すると，

(1) カード式調查はわが国の現状では実施困難であ

り，選転手飞質問する面接式の方が容易かつ確実であ る。

(2) 八ガキ式調左は通常回收率がきわめてわるく效果 が少ない。

(3) 駐車状況一般の大局的把握のためには，ノンプレ 一ト断続式が容易簡便で適当である。

(4) 駐車時間の正確な調査はプレート連続式によらな ければならないが，この方式は最も労力経費を必要とす る。

(5) 駐車場所と目的地との関係は広笧囲にわたる調查 を必要とし，これは真の駐車需要を捕捉するためと必要 な事項である。この調査には面接式が推奖される。

(6) 駐車状況に関して正確な資料をうるためには，プ
レート連続式によらなければならないが，駐車現象は一 種の社会現象であって, 同一状態は 2 度と起こらないと 考えられるから，その大局を把握し，計画と必要な調査 資料をろる方法として，プレート断続式調査に属する方 法であるが，つぎに述べる調査方式に上れば，経費も少 なく容易に広範囲の調査が可能で，また調查結果の補正 も可能である。

\section{5. 駐車実態調查方式の提案とその実測例}

実際飞駐車患態の調査を行なうに当たって，駐車時間 を正確に決定するためには，ある地域に出入する車を全 部連続して観測すればよい。

しかしこの方法では駐車数の多少にかかわらず観測者 そかなり長時間の緊張を強制することになり，また相当 多大の人員と経費を必要とすることになる。したがって この方法は駐車時間の非常飞短い場所とか，特別の目的

表一2 駐車現 況調查用紙

$\begin{array}{lllll}\text { 場 } & \text { 所 } & \text { 河原町 (四条 仏光寺) 西側 } & \text { 調 査 時 間 } & 2.00 \mathrm{PM} \sim 4.10 \mathrm{PM} \\ \text { 日 } & \text { 時 } & \text { 昭和 年 月 日 ( ) } & \text { 観測時間間隔 } & 10 \text { 分 } \\ \text { 延 } & \text { 長 } & 250 \mathrm{~m} \text { 駐:車可能区間 } 164 \mathrm{~m} & \text { 観 測 者 } & \end{array}$

\begin{tabular}{|c|c|c|c|c|c|c|c|c|c|c|c|c|c|c|c|c|}
\hline$x$ & 测番号 & 1 & 2 & 3 & 4 & 5 & 6 & 7 & 8 & 9 & 10 & 11 & 12 & 13 & 14 & 観測回 \\
\hline 車種 & 時刻 & 2.00 & 10 & 20 & 30 & 40 & 50 & 3.00 & 10 & 20 & 30 & 40 & 50 & 4.00 & 10 & 数合計 \\
\hline 5 & 362 & (2) & (2) & & & & & & & & & & & & & 2 \\
\hline 4 & 983 & (13) & (13) & (13) & (13) & (13) & (13) & (13) & (13) & (13) & (13) & (13) & (13) & (13) & & 13 \\
\hline 3 & 156 & (14) & (14) & (14) & (14) & (14) & (14) & (14) & (14) & (14) & (14) & (14) & (14) & (14) & (14) & 14 \\
\hline 5 & 937 & (4) & (4) & (4) & (4) & & & & & & & & & & & 4 \\
\hline 5 & 222 & (14) & (14) & (14) & (14) & (14) & (14) & (14) & (14) & (14) & (14) & (14) & (14) & (14) & (14) & 14 \\
\hline 3 & 258 & (14) & (14) & (14) & (14) & (14) & (14) & (14) & (14) & (14) & (14) & (14) & (14) & (44) & (14) & 14 \\
\hline 3 & 536 & (2) & (2) & & & & & & & & & & & & & 2 \\
\hline 5 & 244 & (14) & (14) & (14) & (14) & (14) & (14) & (14) & (14) & (14) & (14) & (14) & (14) & (14) & (14) & 14 \\
\hline 3 & 036 & (1) & & & & & & & & & & & & & & 1 \\
\hline 3 & 951 & (1) & & & & & & & & & & & & & & 1 \\
\hline 3 & 836 & & (1) & & & & & & & & & & & & & 1 \\
\hline 5 & 765 & & (10) & (10) & (10) & (10) & (10) & (10) & (10) & (10) & (10) & (10) & & & & 10 \\
\hline 3 & 576 & & (1) & & & & & & & & & & & & & 1 \\
\hline 5 & 211 & & & (12) & (12) & (12) & (12) & (12) & (12) & (12) & (12) & (12) & (12) & (12) & (12) & 12 \\
\hline 5 & 002 & & & (1) & & & & & & & & & & & & 1 \\
\hline 5 & 113 & & & (12) & (12) & (12) & (12) & (12) & (12) & (12) & (12) & (12) & (12) & (12) & (12) & 12 \\
\hline 5 & 018 & & & & & (2) & (2) & & & & & & & & & 2 \\
\hline 4 & 143 & & & & & & (2) & (2) & & & & & & & & 2 \\
\hline 5 & 678 & & & & & & (9) & (9) & (9) & (9) & (9) & (9) & (9) & (9) & (9) & 9 \\
\hline 3 & 357 & & & & & & & (5) & (5) & (5) & (5) & (5) & & & & 5 \\
\hline 3 & 468 & & & & & & & & (2) & (2) & & & & & & 2 \\
\hline 5 & 245 & & & & & & & & (3) & (3) & (3) & & & & & 3 \\
\hline 5 & 467 & & & & & & & & (7) & (7) & (7) & (7) & (7) & (7) & (7) & 7 \\
\hline 4 & 538 & & & & & & & & (1) & & & & & & & 1 \\
\hline 5 & 000 & & & & & & & & & (5) & (5) & (5) & (5) & (5) & & 5 \\
\hline 6 & 414 & & & & & & & & & (1) & & & & & & 1 \\
\hline 5 & 132 & & & & & & & & & & (5) & (5) & (5) & (5) & (5) & 5 \\
\hline 5 & 456 & & & & & & & & & & & (1) & & & & 1 \\
\hline 6 & 987 & & & & & & & & & & & (4) & (4) & (4) & (4) & 4 \\
\hline 3 & 754 & & & & & & & & & & & (4) & (4) & (4) & (4) & 4 \\
\hline 5 & 305 & & & & & & & & & & & & & (2) & (2) & 2 \\
\hline 5 & 688 & & & & & & & & & & & & & (2) & (2) & 2 \\
\hline 6 & 735 & & & & & & & & & & & & & (2) & (2) & 2 \\
\hline 6 & 113 & & & & & & & & & & & & & & (1) & 1 \\
\hline 5 & 415 & & & & & & & & & & & & & & (1) & 1 \\
\hline 5 & 188 & & & & & & & & & & & & & & (1) & 1 \\
\hline & & 10 & 11 & 10 & 9 & 9 & 11 & 11 & 14 & 15 & 14 & 16 & 13 & 16 & 17 & 176 \\
\hline
\end{tabular}


以外は不必要であって，つぎに述べる一種のプレート断 続式調查による記帳法にもとづいて, 適当な時間間隔を おいて観測することによってより安価とかつ十分実用的 な資料をろることができる。しかして観測の時間間隔の 選定は要求される精度による。間隔が長いと短時間駐車 を見逃しやすくなり，一方間隔が短いと調查費用が高く なる。この調查方法によれば, 徒歩あるいは写真, 自動 車を利用して小人数で相当広範囲な地域の実測を行なう ことができる。

\section{(1) 調査方法および記帳法}

観測とあたっては調查員に担当の調查区域を指定し， 表一2 (駐車現況調査用紙)のごとき調查用紙を携行せし め, 指定した時間間榢（実測例では10分間隔）ごとに区 域をまわり調查用紙と車種別 (業種別) 招よびプレート ナンバーの下 3 桁を記入せしめる。表の観測番号は指定 した観測時間間隔ごとに観測すべき回数の順番を示す。 観測間隔を一定にするため, 調查貝は巡回方向を一定に し，観測時刻に近づけるようとする。

観測した車をとの観測時刻の下欄に○印をつけ，つぎ の観測時に同じ車があれば，同じ横の欄に○印をつけて ゆき，車がなければ空欄とする。新たに駐車した車は下 欄传き加えてゆく。同じような操作を行ない, 所定の 観測が終った後, 同一車について観測された回数を調べ その観測合計回数を○印の中に記入する。つぎに観測番 号の縦欄ごとに○印を集計すると，その観測時刻と括け る駐車台数を表わす。

\section{(2) 調查結果の解析}

上記駐車現況調查の記録から表一3を作成する。すな わち, 表一2 と招いて○印中の数字は駐車時間の長さ

（観測時間間隔の長さを単位とした）を表わすことにな
るから, 各観測番号ごとの縦欄について, 同一駐車時間 のものの○印の数を合計して表一3 のよろな表につく る。これを全観測番号について集計すれば，表一3の（a） 欄には各駐車時間の長さ別の観測延台数，下段には各観 測番号 (時刻) ごとの駐車台数が表示され, これから駐 車 (集中) 指数が計算される。以下 (b) 欄は平均 1 回

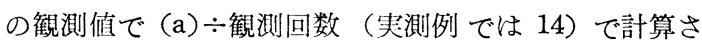
れ，(c) 欄は実駐車台数で (a) $\div$ 駐車時間の長さで算出 される。（d）欄は（c）の央駐車台数を\%で表わしたも ので, (e) 欄は (d) の值を駐車時間の長い方から累積 した值で, これらの值は駐車の場所的特性, その他観測 值の補正などの理論計算に使用するるのである。

上記調査方式は調查員による人力, 写真撮影あるいは 自動車による観測によっても行なうことができ，これら の垁测結果にもとづいて, 表一3 のような時刻別, 駐車 時間長さ別駐車現沉表を作成すれば，これから駐車状沉 の時間的変動, 駐車時間别の台数の頻度など駐車の実態 を知ることができる。

表一3 は予備調査として, 宗都市に招いて行なった丰 測の一例であって, 全調查時間は 2.00 4.10 PM の観測 例に過ぎないが，表からこの観測時間中に実測された実 駐車台数の合計は (c) 欄の計 36 台で, 駐車時間が 30 分以上の車は全体の $47.3 \%$ であり, 平均の駐車指数住 0.52 であるから $0.473 \times 0.52 \div 0.246$, 全体の車のうち 約 $24.6 \%$ は 30 分以上の駐車の車で占められているこ とがわかる。この調查時間中のピークは観測番号 14 , 寸 なわち時刻 4.10 PM のときで, そのときの 17 台の車 のうち 6 台は駐車時間が 30 分以下の車であることがわ かる。

な招平均駐車時間は

\section{表一3 駐車現況集計表}

\begin{tabular}{|c|c|c|c|c|c|c|c|c|c|c|c|c|c|c|c|c|c|c|c|}
\hline \multirow{2}{*}{$\begin{array}{l}\text { 駐車時 } \\
\text { 間の長 } \\
\text { さ }\end{array}$} & \multicolumn{6}{|c|}{ 観 } & 測 & \multicolumn{2}{|l|}{ 番 } & \multicolumn{5}{|l|}{ 号 } & \multicolumn{5}{|c|}{ 駐 車 時 間 長さ別 } \\
\hline & 1 & 2 & 3 & 4 & 5 & 6 & 7 & 8 & 9 & 10 & 11 & 12 & 13 & 14 & 観敗 $(\mathbf{a})$ & $\begin{array}{l}\mid \text { 平均 } 1 \text { 回 } \\
\text { 観測台 } \\
\text { 数 }(\mathrm{b})\end{array}$ & 寒駐車台 & 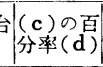 & $\begin{array}{l}\text { (d)の累 } \\
\text { 計(e }\end{array}$ \\
\hline 1 & 2 & 2 & 1 & & & & & 1 & 1 & & 1 & & & 3 & 11 & 0.79 & 11 & 30.5 & 100.0 \\
\hline 2 & 2 & 2 & & & 1 & 2 & 1 & 1 & 1 & & & & 3 & 3 & 16 & 1.14 & 8 & 22.2 & 69.5 \\
\hline 3 & & & & & & & & 1 & 1 & 1 & & & & & 3 & 0.21 & 1 & 2.8 & 47.3 \\
\hline 4 & 1 & 1 & 1 & 1 & & & & & & & 2 & 2 & 2 & 2 & 12 & 0.86 & 3 & 8.3 & 44.5 \\
\hline 5 & & & & & & & 1 & 1 & 2 & 3 & 3 & 2 & 2 & 1 & 15 & 1.07 & 3 & 8.3 & 36.2 \\
\hline 6 & & & & & & & & & & & & & & & & & & & $"$ \\
\hline 7 & & & & & & & & 1 & 1 & 1 & 1 & 1 & 1 & 1 & 7 & 0.50 & 1 & 2.8 & 27.9 \\
\hline 8 & & & & & & & & & & & & & & & & & & & $"$ \\
\hline 9 & & & & & & 1 & 1 & 1 & 1 & 1 & 1 & 1 & 1 & 1 & 9 & 0.64 & 1 & 2.8 & 25.1 \\
\hline 10 & & 1 & 1 & 1 & 1 & 1 & 1 & 1 & 1 & 1 & 1 & & & & 10 & 0.71 & 1 & 2.8 & 22.3 \\
\hline 11 & & & & & & & & & & & & & & & & & & & " \\
\hline 12 & & & 2 & 2 & 2 & 2 & 2 & 2 & 2 & 2 & 2 & 2 & 2 & 2 & 24 & 1.71 & 2 & 5.6 & 19.5 \\
\hline 13 & 1 & 1 & 1 & 1 & 1 & 1 & 1 & 1 & 1 & 1 & 1 & 1 & 1 & & 13 & 0.93 & 1 & 2.8 & 13.9 \\
\hline 14 & 4 & 4 & 4 & 4 & 4 & 4 & 4 & 4 & 4 & 4 & 4 & 4 & 4 & 4 & 56 & 4.00 & 4 & 11.1 & 11.1 \\
\hline 計 & 10 & 11 & 10 & 9 & 9 & 11 & 11 & 14 & 15 & 14 & 16 & 13 & 16 & 17 & 176 & 12.56 & 36 & 100.0 & \\
\hline 駐車指数 & 0.41 & $\mid 0.45$ & 0.41 & 0.37 & 0.37 & 0.45 & $\mid 0.45$ & 0.58 & 0.62 & $\begin{array}{l}0.58 \\
\end{array}$ & $\mid 0.66$ & 0.54 & $\mid 0.66$ & 0.70 & & 0.52 & & & \\
\hline
\end{tabular}


平均駐車時間 $=\frac{(\mathrm{a}) \text { 欄の計 }}{(\mathrm{c}) \text { 欄の計 }} \times$ 镜測時間間隔

で計算される。表一3 の場合とは 48 分となる。

また駐車指数の計算沉必要な許容台数の算出には路上 平行駐車に必要な I台分の駐車スペースは $6.75 \mathrm{~m}$ であ るとして計算したものである。

な抢3.の (4) で定義した駐車需要量の単位として(台 一時）を用いれば, 観測延台数は（a）の計 176 から, $176 \times 1 / 6=29.3$ (台-時) である。

平均占用率は 3.の (6) で定義した值で,

\section{$\frac{\text { 平均駐車台数 }}{\text { 許容台数 }}$}

としても表わされるから，（b）の最下欄 と示す平均駐 車指数の 0.52 が所要の值となる。

な打実測飞当たっては最初と最後の観測の前後に，そ れぞれほぼ観測時間間隔飞等しい時間を扔いて, 補足的 調査を行なえば，駐車時間はいっそう実際汇近くなる。

以上の調査方法ならびに記帳法は, 観測をできるだけ 容易簡便にして, 経費, 手数を節約して, 駐車の実態を 把握しょうとするすのであって, きわめて容易に字用に 供しろるものである。しかし（2）の調査結果の解析に 扔いて述べたことからわかるようと, 短時間の駐車台数 の何パーセントかは調查もれとなり，ここで考兄ている 駐車時間と実際の車の駐車時間とは, 観測時間間隔の長 さの範囲内の違いが生ずることになる。ここにいう駐車 時間はあくまで見掛け上の值であって，実用上は十分利 用しろるものであるが, 䈌密には調查もれの車とともと 調査結果を補正することが必要となる。この補正の方法 抢よびその理論についてつぎに考光てみることとする。

\section{6. 観測值の補正の理論}

\section{(1) 駐車の一般的特性}

一般飞駐車継続時間の分布は指数分布にしたがうもの と考えてよいから, 駐車の全時間てがある与えられた時 間 $t$ をこえる確率はつぎのようと書くことができる ${ }^{18) 。 ~}$$$
\left.P\{\tau>t\}=e^{-l t} \text { ( } l \text { : 正の定数 }\right) \text {. }
$$

駐車継続時間の確率法則が式 (1) としたがうときは,

図-3

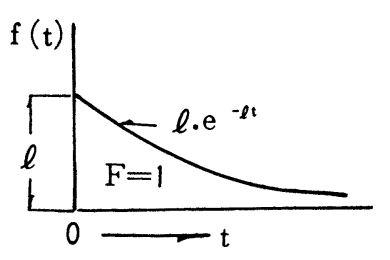

その確率密度 関数 $f(t)$ は次式で与兄られる。 $f(t)=l \cdot e^{-l t},(t \geqq 0)$ $=0, \quad(t<0)\}$

したがって $f(t)$ と $t$ 軸 とで囲まれる面積 $F$ は

$$
F=\int_{0}^{\infty} f(t) d t=\left[-e^{-l t}\right]_{0}^{\infty}=1
$$

であり, 平均駐車時間 $\overline{\boldsymbol{i}}$ は,

$$
\bar{t}=\frac{\int_{0}^{\infty} f(t) \cdot t d t}{F}=\left[-e^{-l t} \cdot t-\frac{1}{l} e^{-l t}\right]_{0}^{\infty}=\frac{1}{l} \cdots \cdots
$$

したがって定数 $l$ は平均駐車時間の逆数であることがわ かる。

\section{（2）観測もれとなる車とその補正}

いま観測の一例として, 観測時間間隔 30 分の調査を 行なった場合を考光ると, 1 回観測の車飞は, 駐車時間! 1 分程度のものから 59 分程度のものまで, 約 1 時間の 幅をもったものをふくむとととなる。これらの車の 1 台 が駐車時間の長さにしたがって, 観測とのる確率はつぎ のよろになる。駐車時間 30 分の車は皆 1 回の観測にの ることとなり，5分のものは観測時刻 5 分前から観測時 刻までに駐車を始めた場合にのみ観測され，観測時間間 隔 (30 分) の $1 / 6$ の確率となる。15 分の車では $1 / 2$ の確率, 45 分では $1 / 2$ (残りの $1 / 2$ は 2 回観測され る), 60 分で 0 (全部 2 回観測される) という確率とな る。いまこれを一般的と考光て, 観測時間間隔を $T$ と すると, 一般に $i$ 回観測される車は駐車時間が $(i T \pm$ $T$ ) の範囲の任意時間駐車しているものである。したが って駐車時間 $t$ が $(i-1) T \sim i T$ 招よび $i T \sim(i+1) T$ の範囲の車が $i$ 回観測される確率をそれぞれ $p_{l}(i)$, $\operatorname{pr}(i)$ とすると,

$$
\left.\begin{array}{l}
p_{l}(i)=\frac{t}{T}-(i-1),[(i-1) T \leqq t \leqq i T] \\
p_{r}(i)=(i+1)-\frac{t}{T},[i T \leqq t \leqq(i+1) T]
\end{array}\right\}
$$

とすることができる。しかるときは駐車時間 $t$ が， $i T$ $\leqq t \leqq(i+1) T$ の車が $i$ 回もしくは $(i+1)$ 回観測され る確率 $P\{i+(i+1)\}$ は,

$$
\begin{aligned}
& P\{i+(i+1)\}=p_{r}(i)+p_{l}(i+1) \\
& \quad=\left\{(i+1)-\frac{t}{T}\right\}+\left\{\frac{t}{T}-i\right\}=1
\end{aligned}
$$

すなわち確率 1 をもって $i$ もしくは $(i+1)$ 回のいずれ かの観測に入ることになるから, 一般に駐車時間が $T$ 以上の車は観測もれとなることはない。

\section{图-4}

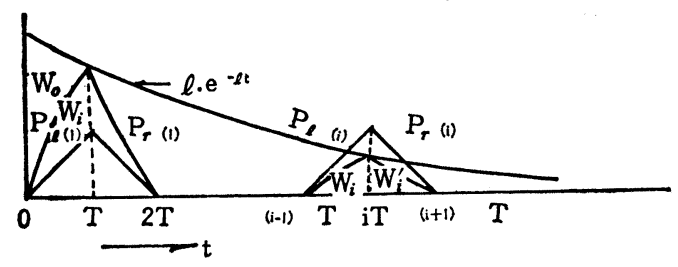

$$
\begin{aligned}
& \text { ただ } 0<t \leqq T \text { の車については式 (5) から. } \\
& p_{r}(0)=1-\frac{t}{T}, \quad(0<t \leq T)
\end{aligned}
$$

なる確率で観測もれを生ずる。すなわち以上のことが， 駐車の全時間を連続調查した場合の結果とくい違った調 査結果を与える招もな原因となるから，その影響扣よび 補正について考㝋てみる。

駐車の特性が式 (2) で与兄られるときは $i$ 回観測さ れるものは 
$\int_{(i-1) T}^{i T} f(t) p_{l}(i) d t+\int_{i T}^{(i+1) T} f(t) p_{r}(i) d t$ にて計算される。上式の第 1 項を $W_{i}$, 第 2 項を $W_{i}{ }^{\prime}$ と すると，

$$
\begin{aligned}
W_{i} & =\int_{(i-) T}^{i T} l \cdot e^{-l t}\left\{\frac{t}{T}-(i-1)\right\} d t \\
& =\left[-e^{-l t}\left\{\frac{t}{T}-(i-1)\right\}-\frac{1}{l T} e^{-l t}\right]_{(i-1) T}^{i T} \\
& =\frac{e^{-i l t}}{l T}\left(e^{l t}-l T-1\right) \cdots \cdots \cdots \cdots \cdots \cdots \cdots(7) \\
W_{i}{ }^{\prime} & =\int_{i T}^{(i+1) T} l \cdot e^{-l t}\left\{(i+1)-\frac{t}{T}\right\} d t \\
& =\left[-e^{-l t}\left\{(t+1)-\frac{t}{T}\right\}+\frac{1}{l T} e^{-l t}\right]_{i T}^{(i+1) T} \\
& =\frac{e^{-i l t}}{l T}\left(e^{-l T}+l T-1\right) \cdots \cdots \cdots \cdots \cdots \cdots \cdots(7)
\end{aligned}
$$

したがって $i$ 回観測されるもの $W(i)$ は，

$$
\begin{aligned}
W(i) & =W_{i}+W_{i}^{\prime}=\frac{e^{-i l T}}{l T}\left(e^{l T}+e^{-l T}-2\right) \\
\text { or } & =\frac{2 e^{-i l T}}{l T}(\cosh l T-1) \\
\text { or } & =\frac{4 e^{-i l T}}{l T} \sinh ^{2} \frac{l T}{2}
\end{aligned}
$$

つぎと観測もれとなるもの $W_{0}$ は $W_{1}$ と駐車時間が $T$ 以上のものとの和を全体から引けば求められるから,

$$
\begin{aligned}
& W_{0}=1-\left\{W_{1}+\int_{T}^{\infty} l e^{-l t} d t\right\} \\
& =1-\frac{e^{-l T}}{l T}\left(e^{l T}-l T-1\right)-e^{-l T} \\
& =\frac{1}{l T}\left(e^{-l T}+l T-1\right)
\end{aligned}
$$

すなわち 全車両の内式 (9) で与えられる割合のものが 観測されないことになる。

\begin{tabular}{|c|c|c|c|c|c|c|}
\hline \multirow{2}{*}{$\begin{array}{c}\text { 平均駐車時間 } \\
1 / l \text { (分) }\end{array}$} & \multicolumn{6}{|c|}{ 観測時間間隔 $T$ (分) } \\
\hline & 0 & 5 & 10 & 15 & 20 & 30 \\
\hline 30 & 0 & 7.8 & 14.8 & 21.3 & 27.0 & 36.8 \\
\hline 60 & 0 & 4.0 & 7.8 & 11.5 & 14.8 & 21.3 \\
\hline
\end{tabular}

観測される全体を $W$ とすれば,

$$
W=1-W_{0}=\frac{1}{l T}\left(1-e^{-l T}\right)
$$

であるから，いま $W$ 亿対する $W_{0}$ の割合を求めると，

$$
\frac{W_{0}}{W}=\frac{e^{-l \boldsymbol{T}}+l T-1}{1-e^{-l \boldsymbol{T}}}
$$

また $W(1)$ に対する $W_{0}$ の割合は，

$$
\frac{W_{0}}{W(1)}=\frac{e^{-l \boldsymbol{T}}+l T-1}{2 e^{-l T}(\cosh l T-1)}
$$

すなわち，式 (9)，(11)，(12）のいずれかを用いて観 測もれの台数を推定することができる。

いま計算の一例を示すと 表一4 のごとくなる。

い未式 (9),(11),(12) の值をlT を横軸にとって計 算した值を示すと 図一5 のようになる。

また駐車場計画に当たって考慮しなければならない全
図一5

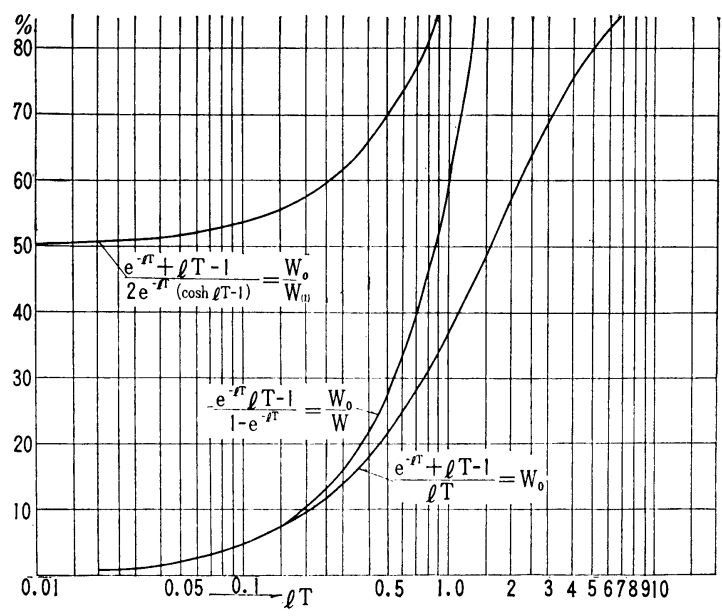

図一6

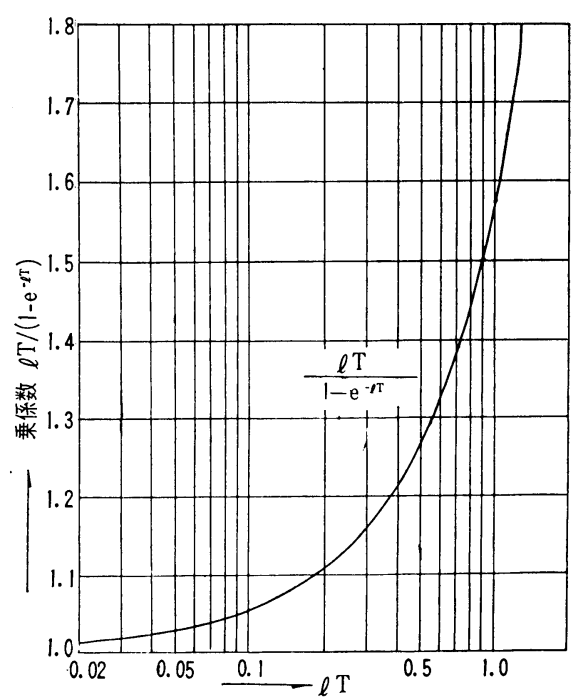

台数は観測尖台数〔駐車現況集中 表一3の（c）欄の計 の值】を $\left(1-W_{0}\right)$ の值で割れば求められるから式 (10) を参照して,

$$
\text { 全台数 }=\text { 観測実台数 } \times \frac{l T}{1-e^{-l T}}
$$

上式の乗係数 $l T /\left(1-e^{-l T}\right)$ の值を示すと図一6 のごと くである。

\section{（3）補正量とその 平均駐車時間}

a) 観測子れに対す る平均駐車封間 観 測もれ $W_{0}$ の平均駐車 時間を $\overline{\boldsymbol{t}}_{0}$ とすると, 図一7 亿抢いて曲線 $0 b$ 図-7 の方程式は式 (5) を参照して $l e^{-l t} ・ t / T$ であるから， 


$$
\bar{t}_{0}=\frac{\int_{0}^{T} l e^{-l t}(1-t / T) t d t}{W_{0}}
$$

上式の分子 $=\int_{0}^{T} l e^{-l t}\left(t-t^{2} / T\right) d t$

$$
\left.\begin{aligned}
& =\left[-e^{-l t}\left(t-t^{2} / T\right)-\frac{e^{-l t}}{l}\left(1-\frac{2 t}{T}\right)+\frac{2}{l^{2} T} e^{-l t}\right]_{0}^{T} \\
& =\frac{1}{l^{2} T}\left\{2\left(e^{-l T}-1\right)+l T\left(e^{-l T}+1\right)\right\} \\
\therefore & \bar{t}_{0}=\frac{1}{l} \frac{l T\left(1+e^{-l T}\right)-2\left(1-e^{-l T}\right)}{e^{-l T}+l T-1} \\
& =\left[\text { 平均駐車時間] } \times M_{0}\right. \\
& \text { ただし } M_{0}=\frac{l T\left(1+e^{-l T}\right)-2\left(1-e^{-l T}\right)}{e^{-l T}+l T-1}
\end{aligned}\right|^{\cdots(14)}
$$

b) 特定の駐車時間以下のbのを除外した場合の補.I 奏祭の駐車場の計画に 図-8 扣いては, 短時間駐車の ものは棓画から除外する ことが行なわれるから，

いま駐車時間が $\beta$ 以下の ものは除くものと考える と, 図一8 の斜線の部分

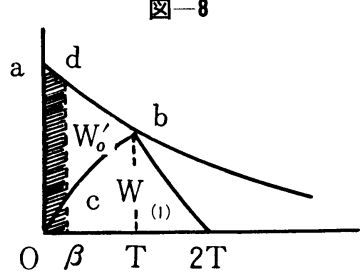
を計算から除外すればよいことになる。したがって当然 計画上考慮すべきもののうち，W $W_{0}^{\prime}$ が観測もれとなり， 一方除外すべきもののうち面積 $0 c \beta$ の部尔が $W(1)$ の 中に観測せられているからこれをW(1)のうちから引き 去ればよいことになる。

$$
\begin{aligned}
W_{0}^{\prime} & =\int_{\beta}^{T} l \cdot e^{-l t}\left(1-\frac{t}{T}\right) d t \\
& =\left[-e^{-l t}\left(1-\frac{t}{T}\right)+\frac{e^{-l t}}{l T}\right]_{\beta}^{T} \\
& =\frac{e^{-l T}+l T e^{-l \beta}(1-\beta / T)-e^{-l \beta}}{l T}
\end{aligned}
$$

また $W_{0}^{\prime}$ と対する平均駐車時間を $\bar{t}_{0}^{\prime}$ とすれば，

$$
\begin{aligned}
\overline{\boldsymbol{t}}_{0}^{\prime}= & \frac{\int_{\beta}^{T} l \cdot e^{-l t}\left(1-\frac{t}{T}\right) t d t}{W_{0}^{\prime}} \\
= & \frac{1}{W_{0}^{\prime 2} l T}\left[2\left(e^{-l T}-e^{l \beta}\right)\right. \\
& +l T\left\{e^{-l T}+e^{-l \beta}\left(1-\frac{2 \beta}{T}\right)\right\} \\
& \left.+l^{2} T e^{-l \beta}\left(\beta-\frac{\beta^{2}}{T}\right)\right] \\
= & \frac{1}{l} \cdot \frac{e^{-l T}(2+l T)+l T e^{-l \beta}(1-2 \beta / T)}{e^{-l T}+l T e^{-l \beta}(1-\beta / T)} \\
& * \frac{-2 e^{-l \beta}+l^{2} T e^{-l \beta}\left(\beta-\beta^{2} / T\right)}{-e^{-l \beta}}
\end{aligned}
$$

上式に抳いて， $\beta=0$ のときは式（14）に等しくなる。 つぎに $0 c \beta$ の部分が全体に占める制合は，

$$
{ }_{0} \Delta_{\beta}^{c}=\int_{0}^{\beta} l \cdot e^{l t} \frac{t}{T} d t=\frac{e^{-l \beta}\left(e^{l \beta}-l \beta-1\right)}{l T} \ldots
$$

したがって $0 c \beta$ の部分が駐車時間 $T$ なる锥測值す なわち $W(1)$ に対する比率は式（8）を用いて，

$$
\frac{{ }_{c}^{0} \Delta_{\beta}^{0}}{W(1)}=\frac{e^{-l \beta}\left(e^{l \beta}-l \beta-1\right)}{e^{-l T}\left(e^{l T}+e^{-l T}-2\right)}
$$

すなわち $W(1)$ に相当する観測実台数から式 (18) で示 される割合を差し引いたものを駐車時間が $T$ に相当す る台数とすればよいことになる。実際上の問題としては 観測もれとなるものの全体 $W_{0}$ を推定して全台数を求 めそのうち駐車時間が $\beta \sim T$ の範囲のものを計算して, それを差し引く方が計算が容易であろろ。
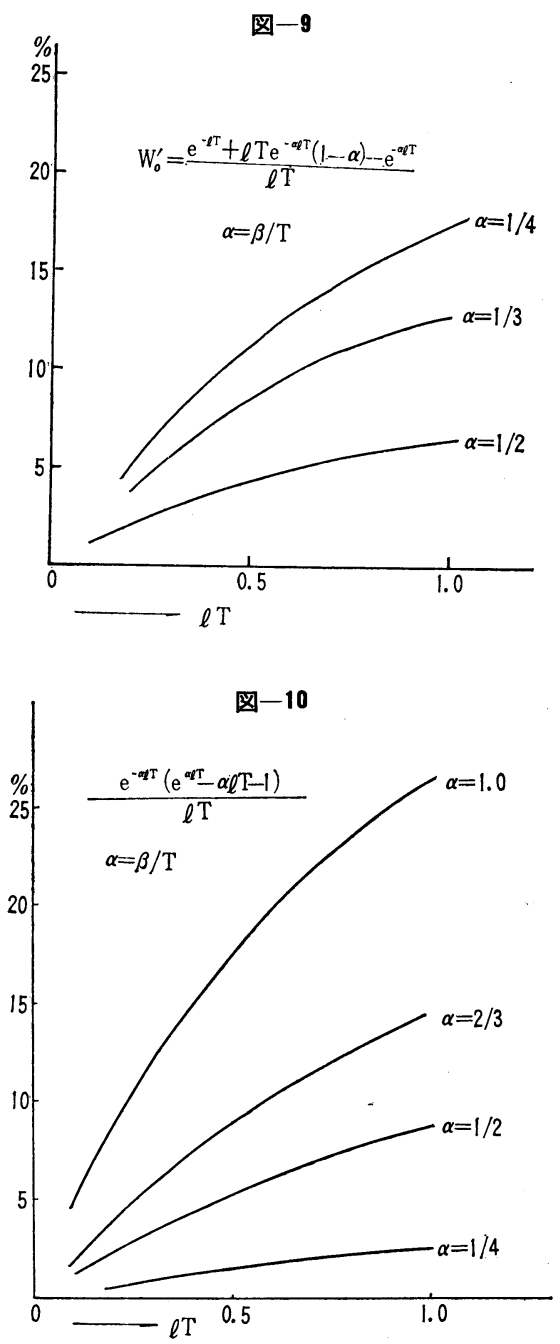

式 (15) で与えられる観測もれとなるものの割合 $W_{0}^{\prime}$ を $\alpha=\beta / T$ と打いて $\alpha$ の㬰用範囲の 值について計算し た值を示すと図一9 のようになる。また同様と式 (17) で与えられる 1 回観測のデータ W(1) から除外しなけれ ばならないものの割合を計算すると図一10のようにな る。

\section{（4）駐車継続時間を連続調査した場合との相違}

a) 統計的処理方法に起因する䛊差 いま観測の時 間間隔を $T$ として調査を行なった場合， $i$ 回観測され 
た車の駐車時間は iTであるとして 集計を行なうこと となる。これを別 の言葉でいえば 「調查中 $i$ 回観測 される車の台数は $i T$ 時間駐車して いる車の台数に等
図-11

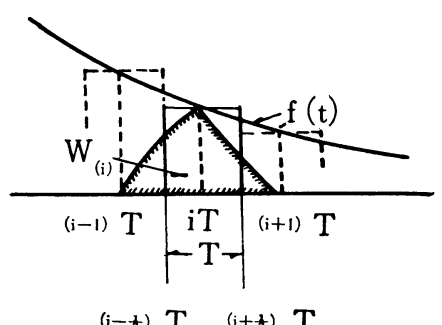

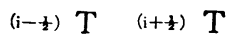

しい」と仮定して計算を進めることになるが，これらの 車は先に述べたごとく， $i T \pm T$ 時間中の任意時間駐車 しているから䈌密には正しくない。しかして $i$ 回観測さ れるものは, 式 (8) とて与えられる 図-11のW(i)の 部分である。

一方駐車の全時間を調查した場合に $i T$ 時間駐車する 車は統計処理上 $(i T \pm T / 2)$ のものをとることになるか ら $i T$ 時間駐車するものの台数は,

$$
l \cdot e^{-i \boldsymbol{T}} \times T
$$

したがって式（8）と式（19）との比をとると，

$$
\begin{gathered}
\frac{\frac{4 e^{-i l T}}{l T} \cdot \sinh ^{2} \frac{l T}{2}}{l T e^{-i l T}}=\left(\frac{\sinh l T / 2}{l T / 2}\right)^{2} \div 1+\frac{(l T)^{2}}{12} \\
{\left[\because \sinh x=x+\frac{x^{3}}{3 !}+\frac{x^{4}}{5 !}+\cdots \cdots\right]}
\end{gathered}
$$

すなわち調查結果のくい違いは $i$ には無関係にほほ $(l T)^{2} / 12$ で与えられる。したがって $l$ が一定の場合に は $T$ が大すなわち観測の時間間隔が大となるほど誤差 は大きくなる。いま $l T$ を変数と考えた場合の $(l T)^{2} / 12$ の值を示すと 図一12 のようになる。

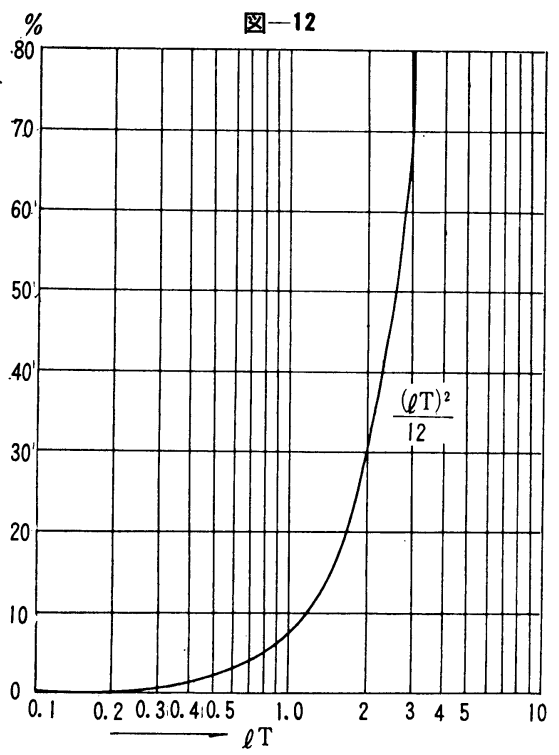

いま $l T=0.5$ なる場合の一例として，平均駐車時間 が 60 分であるとき, すなわち 30 分間隔の観測を行なっ た場合を考えてみると，そのくい違いは約 $2.1 \%$ であ
るにすぎない（図一12 参照)。

b) 仮想的無限調查を行なった場合との誤差 駐車 は一種の社会現象であって，これを統計的にみれば 24 時間を周期として，大体同じような変化をしているもの と考えられるが, 個々の駐車については 2 度とは起こり 得ない現象である。これを総括的に眺め現象を統計的に 数式化して考えると, その生起の確率が 密度関数 $f(t)$ にしたがうことになるのである。したがって密度関数 $f(t)$ は無限の連続調查を行なうことにより決定される ことになる。いまその極限に招いて確率密度関数 $f(t)$ が連続関数として与えられたものと考えると, 駐車時間 が $i T$ であるものはつぎの積分とより与えられる。

$$
\int_{(i+1 / 2) T}^{(i+1 / 2) T} l \cdot e^{-l t} d t=2 e^{i l t} \sinh \frac{l T}{2} .
$$

W(i) との比を求めると,

$$
\frac{4 e^{-i l T} \sinh ^{2} \frac{l T}{2}}{2 l T e^{-i l T} \sinh \frac{l T}{2}}=\frac{\sinh \frac{l T}{2}}{\frac{l T}{2}} \div 1+\frac{(l T)^{2}}{24} .
$$

すなわち，この場合の䛊差は a) の場合の $1 / 2$ となるこ とがわかる。しかしこの場合の啡差は問題の処理上, 現 串には行ないえない仮想的な場合の理論誤差であるか ら，実際上は式 (20) で与えられる大きさをその誤差と 考えればよい。

\section{(5) 駐車時間の補正}

観測資料を整理すると際して，i回観測された車の駐 車時間はいずれる $i T$ 時間であると考学て計算を行なう が $W$ (2) 飞属する車の平均駐車時間を $\bar{t}_{i}$ とすると， $\bar{t}_{i}$ 㹥次式により計算される。

$$
\bar{t}_{i}=\frac{\int_{(i-1) T}^{i T} f(t) \cdot p_{l}(i) t d t+\int_{i T}^{(i+1) T} f(t) \cdot p_{r}(i) t d t}{W(i)}
$$

上式の

$$
\begin{aligned}
& \text { 分子の第 } 1 \text { 項 }=\int_{(i-1) T}^{i T} l \cdot e^{-l t}\left\{\frac{t^{2}}{T}-(i-1) t\right\} d t \\
& =e^{-i l T}\left\{-i T-\frac{i+1}{l}-\frac{2}{l^{2} T}\left(1-e^{l T}\right)+\frac{e^{l T}}{l}(i-1)\right\}
\end{aligned}
$$

分子の第 2 項 $=\int_{i T}^{(i+1) T} l \cdot e^{-l t}\left\{(i+1) t-\frac{t^{2}}{T}\right\} d t$

$$
=e^{i l r}\left\{i T-\frac{i-1}{l}-\frac{2}{l^{2} T}\left(1-e^{-l T}\right)+\frac{e^{-l T}}{l}(i+1)\right\}
$$

したがって

$$
\begin{gathered}
\text { 分子 }=e^{-i l T}\left\{\frac{-2 i}{l}+\frac{4}{l^{2} T}(\cosh l T-1)\right. \\
\left.+\frac{2 i}{l} \cosh l T-\frac{2}{l} \sinh l T\right\} \\
\therefore \bar{t}_{i}=\frac{\text { 分 }}{\frac{2 e^{-i l T}}{l T}(\cosh l T-1)}=i T+\frac{1}{l}\left\{2-\frac{l T \sinh l T}{\cosh l T-1}\right\}
\end{gathered}
$$

いま $\left(\bar{t}_{i}-i T\right)=\Delta t$ として $\Delta t$ を駐車時間の補正量と いうことにすれば, 
图-13

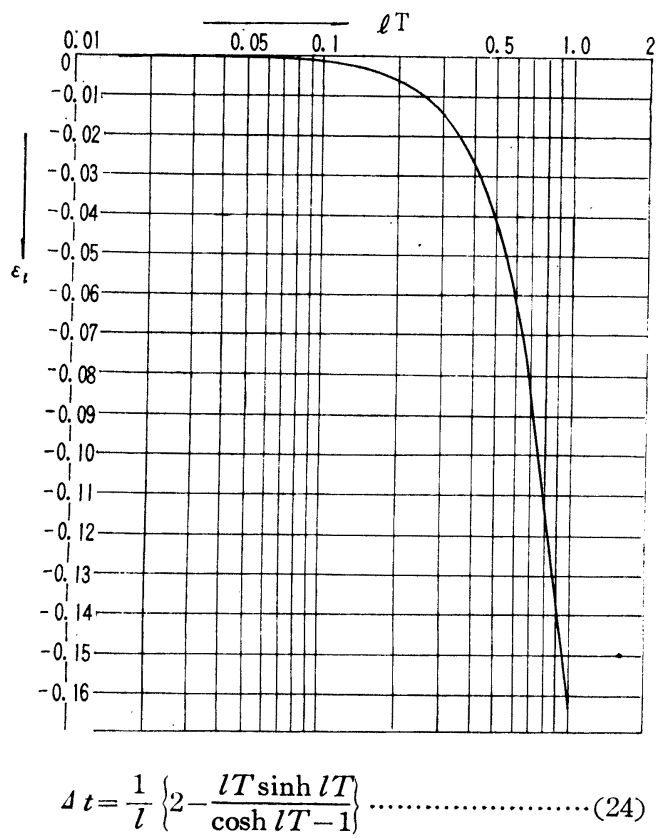

となり $\Delta t$ は $i$ には無関係な一定の值となる。式 (24) の \{\}の中の值を $\varepsilon_{t}$ と䈯き，これを駐車時間補正係数 とよぶことにすると，

$\Delta t=$ [平均駐車時罩 $] \times \varepsilon_{t}$

な报 $\varepsilon t$ を種々なる $l T$ の值に対して計算すると 図-13 の曲線のようになる。

（6）実測資料から平均駐車時間 $1 / l$ を算定する方法

いままで述べてきたことによって，観測もれその他备 種の補正を行なうためには, 確率密度曲線の特性を示す $l$ の值を知る

ことが必要と なってくる。 しかるに観測 資料は $W_{0}$ を 除いた部分し か得られてい

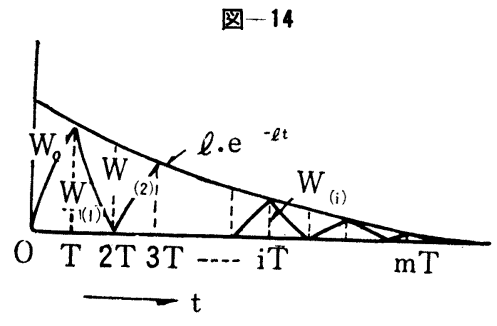
ない。したが

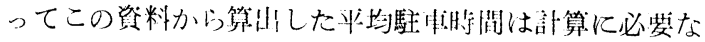

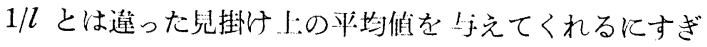
ない。いまこの兒掛け上の平均駐事時間の值を $1 / l_{a}$ と すると次式で計算できる（表-3 参照）。

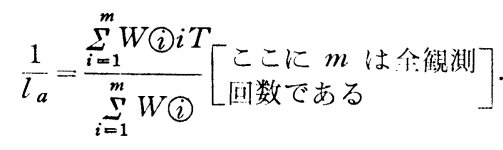

上式に式 (8) のW(i) の侐を代人すると，

$$
\begin{aligned}
& \text { 分來 }=K \cdot \sum_{i=1}^{m} e^{-i l T} \\
& \text { 分子 }=T \cdot \sum_{i=1}^{m} \sum i e^{-i l T}
\end{aligned}\left[\text { ただし } K=\frac{e^{l T}+e^{-l T}-2}{l T}\right]
$$

分母, 分子の共通因数 $K$ を約行したあとの值をそれぞ れ $S, U$ と执き

$$
e^{-l T}=x
$$

と打くと,

$$
\begin{aligned}
S & =\sum_{i=1}^{m} x^{i}=x+x^{2}+\cdots \cdots+x^{m}=\frac{x\left(1-x^{m}\right)}{1-x} \\
U & =T \sum_{i=1}^{m} i x^{i}=T\left(x+2 x^{2}+\cdots \cdots+m x^{m}\right) \\
& =\left\{\frac{\left(1-x^{m}\right) x}{(1-x)^{2}}-\frac{m x^{m+1}}{1-x}\right\} T \cdots \cdots \cdots \cdots \cdots \cdots \cdots \cdots \cdots \cdots \cdots \cdots \cdots \cdots \cdots \cdots \cdots \cdots
\end{aligned}
$$

したがって，つぎの関係が成立する。

$$
\frac{1}{l_{a}}=\frac{U}{S}=\left\{\frac{1}{1-x}-\frac{m x^{m+1}}{x\left(1-x^{m}\right)}\right\} T
$$

計算すると，

$$
\begin{aligned}
&\left(m l_{a} T-1\right) x^{m+1}-\left\{(m+1) l_{a} T-1\right\} x^{m} \\
&+x+l_{a} T-1=0 \quad \ldots \ldots \ldots \ldots \ldots \ldots \ldots \ldots \ldots . . .
\end{aligned}
$$

なる简次方程式がえられる。この方程式の係数はすべて 夹測值から決定できる值であるから一般に解くことがで きる。いまその 1 つの奖根を $x_{1}$ とすると式 (26) から $l$ を求めることができる。すなわち

$$
l=\frac{-\log _{e} x_{1}}{T}
$$

として計算することができる。

つぎに $|x|<1$ であるから $m$ がかなり大きい数であ るときは近似的に

$$
S \doteqdot \frac{x}{1-x}, U \doteqdot \frac{x}{(1-x)^{2}} T
$$

となるから

$$
\begin{aligned}
& \frac{1}{l_{a}}=\frac{T}{1-x} \\
& \therefore x=1-l_{a} T .
\end{aligned}
$$

から $x$ の值を求め, 式 (30) の部算を行なって, $l$ の值 㞗めることができる。

政密にはこのようにして求めた $l$ の值を第 1 近似值と して, 式 (24) に示す駐車時間の補正量 $\Delta t$ を計算し, $\Delta t$ 孝慮した場合について，式（25）に示した見掛け 上:の平均駐車時間と钼測值との関係から, 以下いまここ に述べたと同様な計算をくり返えして $l$ の正しい值を求 めていけば, これら眐述のすべての補正值, 站差なども 求めることができる。

また尖用的には, 調查区域中の二, 三の標本調査地点 について, 駐車の全時間の連続調査を行ない, これから 求めた $l$ の值を用いて既述の备種の補正を行なうことも できる。

\section{（7）補正に関するより進歩的な解法}

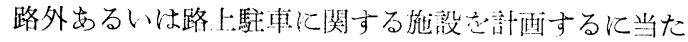
ってはごく知㭙間の駐目は除外して考克られることが多 い。しかるに駐車の尖態を知るために駐車継続時間を速 綎観測によって調榃するときは，計画に不必要な相当多 
数の車とついてもかなり の経費と時間を費して観 測し，集められた資料か ら定められた特定の駐車 時間 $\beta$ 以下のものを除く ためのむだな費用と手数 を掛けなければならな い。

したがって $\beta$ 以下の部
1)

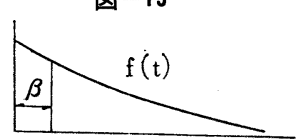

2)

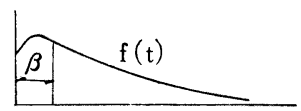

3)

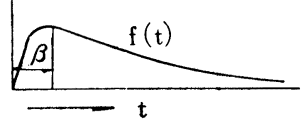

分を除いたものとついて

駐車時間の分布を考兄，適当な補正を行なう方法を考兄 ればよい。

実測によると駐車時間の分布は図一15 亿示すような いろいろな分布をなし，必ずしもいままで論じてきたよ うな完全な指数分布にしたがうとは限らない。したがっ て駐車時間が $\beta$ 以上のものについては, 次式に示すよう な確率密度関数にしたがい， $\beta$ 以下のもので観測に入る 部分を資料から差し引くことを考光る。

すなわち

$$
\begin{aligned}
& \text { A) } f(t)=l^{\prime} e^{-l^{\prime}(t-\beta)},(t>\beta) \\
& =l^{\prime}, \quad(t \leqq \beta)
\end{aligned}
$$

なる密度関数にしたがうと考劣ると， $\beta$ 以上の部分につ いて式 (3),(4) と同じょうにして

$$
\text { 面積 }=\int_{\beta}^{\infty} l^{\prime} e^{-l^{\prime}(t-\beta)} d t=1
$$

この場合の平均駐車時間を $\overline{\boldsymbol{t}}$ とすると，

$$
\bar{t}=\int_{\beta}^{\infty} l^{\prime} e^{-l^{\prime}(t-\beta)} t d t=\frac{1}{l^{\prime}}+\beta
$$

したがって $l^{\prime}$ は,

$$
l^{\prime}=\frac{1}{(\bar{t}-\beta)} .
$$

飞て与えられる定

数である。

観測回数 1 回の 資料中には図一16 そ示す $0 c \beta$ の部 分が付加されるこ とになるから、こ の部分の計算を行

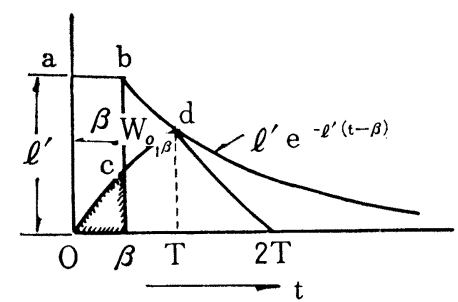
なうため, $t \leqq \beta の$

場合の分布を考兄て，図一15を参照し，その分布を式 (31) 飞示す $f(t)=l^{\prime}$ なる式で近似せしめることにする と,

$$
{ }_{0} \triangle_{\beta}^{c}=\int_{0}^{\beta} l^{\prime} \frac{t}{T} d t=\frac{l^{\prime} \beta^{2}}{2 T}
$$

観測もれとなる部分 $b c d$ については，

$$
\begin{aligned}
{ }_{c}^{b}>d & =W_{0 \beta}=\int_{\beta}^{T}\left\{l^{\prime} e^{-l^{\prime}(t-\beta)}-l^{\prime} e^{-l^{\prime}(t-\beta)} \frac{t}{T}\right\} d t \\
& =\frac{1}{l^{\prime} T}\left\{e^{-l^{\prime}(T-\beta)}+l^{\prime} T-1-l^{\prime} \beta\right\} \cdots \cdots(34)
\end{aligned}
$$

またその平均駐車㭙滥 $\overline{\boldsymbol{t}}_{0 \beta}$ は，

$\overline{\boldsymbol{t}}_{0 \beta}=\frac{\int_{\beta}^{T} l^{\prime} e^{-l^{\prime}(t-\beta)}\left(1-\frac{t}{T}\right) t d t}{W_{0} \beta}$

$$
=\frac{1}{l^{\prime}} \frac{e^{-l^{\prime}(T-\beta)}\left(l^{\prime} T+2\right)+l^{\prime} T-2-l^{2} \beta^{2}+l^{\prime 2} T \beta-2 l^{\prime} \beta}{e^{-l(T-\beta)}+l^{\prime} T-1-l^{\prime} \beta}
$$$$
\overline{\boldsymbol{t}}_{0 \beta}=(\overline{\boldsymbol{t}}-\beta) M_{0}^{\prime}
$$

ただし

$$
M_{0}{ }^{\prime}=\frac{e^{-l^{\prime}(T-\beta)}\left(l^{\prime} T+2\right)+l^{\prime} T-2-l^{\prime 2} \beta^{2}+l^{\prime 2}+\beta-2 l^{\prime} \beta}{e^{-l^{\prime}(T-\beta)}+l^{\prime} T-1-l^{\prime} \beta}
$$

またこの場合 1 回だけ観測されるるのは 図一16の

$$
{ }_{0} \triangle_{\beta}^{c}+{ }_{\beta}^{c} \square_{T}^{\beta}+{ }_{T}^{d} \triangle_{2 T}=W(i)
$$

で左辽の第 1 项は式 (33) で与完られ，第2 項は

$$
\begin{aligned}
{ }_{\beta}^{c} \square_{1}^{d} & =\int_{\beta}^{T} l^{\prime} e^{-l^{\prime}(t+\beta)} \frac{t}{T} d t \\
& =\frac{-e^{l^{\prime}(T-\beta)}}{l^{\prime} T}\left\{1+l^{\prime} T-e^{l^{\prime}(T-\beta)}\right\}+\frac{\beta}{T}
\end{aligned}
$$

第 3 項は

$$
\begin{aligned}
{ }_{T}^{d} \triangle_{2 T} & =\int_{T}^{2 T} l^{\prime} e^{-l^{\prime}(t-\beta)}\left(2-\frac{t}{T}\right) d t \\
& =\frac{e^{-l^{\prime}(T-\beta)}}{l^{\prime} T}\left(e^{-l^{\prime} T}+l^{\prime} T-1\right) \cdots \cdots \cdots \cdots(37) \\
\therefore W(\mathbb{D} & =\frac{e^{-l^{\prime}(T-\beta)}}{l^{\prime} T}\left\{l^{l^{\prime}(T-\beta)}+e^{-l^{\prime} T}-2\right\}+\frac{\beta}{T}+\frac{l^{\prime} \beta^{2}}{2 T}
\end{aligned}
$$

とくに観測時間間隔 $T$ を $\beta$ に等しくとった場合は，

$$
W 1^{\prime}{ }^{\prime}=\beta=\frac{1}{l^{\prime} T}\left(e^{-l^{\prime} T}+l^{\prime} T-1\right)+\frac{l^{\prime} T}{2} \cdots
$$

となり，右辺の第 2 項は計画対象以下の駐車時間の車で 占められる割合であるから $W(10$ T- $\beta$ の観測 資料から $l^{\prime} T / 2$ を引き去った部分のみ沉つて考兄，以下先飞述 ベたような計算手続きを踏めばよいことになる。

B)つぎ駐車眭間が $\beta$ 以下の部分の分布が式 (31) でなく，図一15の3）に示すような分布にしたがう場 合には, $\beta$ 以下の部分の分布が近似们に次式の上万な一 次式にしたがうものと考光ると，

$$
f(t)=l^{\prime} \frac{t}{\beta} \quad(t \leqq \beta)
$$

駐車侍間が $\beta$ 以下のもので観測同数 1 回の資料中に锶椡 されるものは式 (33) に準じて,

$$
\int_{0}^{\beta} l^{\prime} \frac{t}{\beta} \frac{t}{T} d t=\frac{l^{\prime} \beta^{2}}{3 T}
$$

となり, 観測もれとなるものは武 (34) で与兄られる。 この場合 1 回镀測されるものは式 (38) を参照して

$$
W \mathbb{D}=\frac{e^{-l^{\prime}(T-\beta)}}{l^{\prime} T}\left\{e^{l^{\prime}(T-\beta)}+e^{-l^{\prime} T}-2\right\}+\frac{\beta}{T}+\frac{l^{\prime} \beta^{2}}{3 T}
$$

Tを及に等しくとって観測した場命には，

$$
W(10)=\frac{1}{l^{\prime} T}\left(e^{-l^{\prime} T}+l^{\prime} T-1\right)+\frac{l^{\prime} T}{3} \cdots
$$

㣌画に当たっては 1 回観測の資料から $l^{\prime} \beta^{2} / 3 T$ (または 
l'T/3) を差し引いたものを考えればよいことになる。

C) 特別な場合として駐車時間が $\beta$ 以下のもので観測 に入るものと $(\beta \sim T)$ の範用で 観測もれとなるものと が等しくなるような観測時間間隔 $T$ について考えると 式 (33) と（34）を等しいと㨟いて

$$
\begin{aligned}
& \frac{l^{\prime} \beta^{2}}{2 T}=\frac{1}{l^{\prime} T}\left\{e^{-l^{\prime}(T-\beta)}+l^{\prime}(T-\beta)-1\right\} \\
& \therefore e^{-l^{\prime}(T-\beta)}+l^{\prime}(T-\beta)=1+\frac{\left(l^{\prime} \beta\right)^{2}}{2} \\
& l^{\prime}(T-\beta)=y
\end{aligned}
$$

と扰くと，

$$
e^{-y}+y-1-\frac{\left(l^{\prime} \beta\right)^{2}}{2}=0
$$

なる超越方程式をうる。この方程式の定数項は一般に定 まった值であるから，数值計算により近似的に方程式を 解くことができる。たとえばニュートンの方法によれば よい。

求めた $y$ の值を式 (43) 飞代入して所要の $T$ の值を 求めることができる。な打近似解として

$$
e^{-y}=1-y+\frac{y^{2}}{2 !}+\cdots \cdots
$$

として第 3 項までとって考えると式 $\left(42^{\prime}\right)$ は,

$$
y^{2} \doteqdot\left(l^{\prime} \beta\right)^{2} \quad \therefore y \div l^{\prime} \beta
$$

中元式 (43) 加

$$
T-\beta \doteqdot \beta \quad \therefore T \div 2 \beta
$$

ゆえに $2 \beta$ なる時間間隔で観測したときの 1 回観測の 資料は所要の台数を与えてくれることになる。このとき には平均駐車時間の補正のみを行なえばよいことにな る。すなわちこの場合, 観測もれとなると考えられるも のの割合は式 (33) に扣いて $T=2 \beta$ と招いて,

$$
W_{0 \beta}=\frac{l^{\prime} \beta}{4}
$$

その平均駐車時間の補正は式 (35) 洏ら,

$$
M_{0}^{\prime}=\frac{2 e^{-l^{\prime} \beta}\left(l^{\prime} \beta+1\right)+l^{\prime 2} \beta^{2}-2}{e^{-l^{\prime} \beta}+l^{\prime} \beta-1}
$$

にて計算できる。 $\beta$ 以下の部分が式 (39) の分布にした がうと考光た場合も同様に解くことができる。

\section{(8) 計 算 例}

表一3の夹測例について, 補正の理論を適用した計算 例を示すと観測時間間隔 $T=10$ 分, 観测資料にもとつ く見掛け上の平均駐車時間 $1 / l_{a}=48$ 分, したがってl の值を求めるため, 近似式として式 $\left(29^{\prime}\right)$ を用いると

$$
\begin{array}{rl} 
& x=e^{-l T}=1-\frac{10}{48} \div 0.792 \\
\therefore l & l T=-\log _{e} 0.792 \div 0.233 \\
\therefore & l \doteqdot 0.0233 \\
\text { したがって }
\end{array}
$$

$$
\text { 平均駐車時間 } \frac{1}{l}=42.9 \text { 分 }
$$

つぎに観測実台数に対する観測もれの台数の割合は式

(11)(あるいは 図-5 のグラフ) から求めて,

$$
\frac{W_{0}}{W}=\frac{e^{-l T}+l T-1}{1-e^{-l T}}=0.119
$$

$\therefore$ 観測もれの台数 $=36$ 台 $\times 0.119 \fallingdotseq 4$ 台

$\therefore$ 全駐車奏台数 $=36$ 台 +4 台 $=40$ 台

この計算はまた式 (13)（あるいは図一6のグラフ）から 全駐車实台数 $=36$ 台 $\times \frac{l T}{1-e^{-l T}}=36$ 台 $\times 1.11 \fallingdotseq 40$ 台 として求めることもできる。

つぎにこの 4 台の観測もれの車に対する平均駐車時間 ( $\left.\overline{\boldsymbol{t}}_{0}\right)$ अ式 (14) 加

$$
\begin{aligned}
& M_{0}=\frac{l T\left(1+e^{-l T}\right)-2\left(1-e^{-l T}\right)}{e^{-l T}+l T-1} \\
&=\frac{0.233(1+0.792)-2(1-0.792)}{0.792+0.233-1}=0.04 \\
& \therefore \bar{t}=\frac{1}{l} \times M_{0}=42.9 \text { 分 } \times 0.04=1.7 \text { 分 } \\
& \text { したがって観測 むれの車 } 4 \text { 台を考慮した場合の } \\
& \text { 駐車需要量 }=4 \times 1.7+176 \times 10=1766.8 \text { (台-分) } \\
&=29.5 \text { (台-時) }
\end{aligned}
$$

ゆえに求むる平均駐車時間は,

$1766.8 \div 40=44.2$ (分)

な打敩密には式 $\left(24^{\prime}\right)$ あるいは図一13 に示した駐車特 間の補正係数 $\varepsilon_{t}$ とよって補正すると，

\begin{tabular}{|c|c|c|c|c|c|c|c|c|}
\hline 駐車許容台数 & 実註車台数 & 平均回転率 & 最大酫車台数 & 最大駐車指数 & 平均駐車台数 & 平均占用率 & 駐車需要量 & 平均駐車時間 \\
\hline 24 台 & 40 台 & 1.67 & 17 台 & $70 \%$ & 12.56 台 & $52 \%$ & 29.5 台一時 & 43.8 分 \\
\hline
\end{tabular}

$$
\varepsilon_{t}=-0.01 \text { となるから }
$$

所要の平均駐車時間 $=44.2 \times(1-0.01) \div 43.8$ (分) これから計画に必要な駐車実態を示す值を計算すればよ い。すなわち 1 台分の駐車スペースを $6.75 \mathrm{~m}$ とすれば

駐車許容台数 $=164 \div 6.75 \div 24$ (台)

となり, 実駐車台数は上に述べた補正計算から 40 台で あるから

平均回転率 $=40 \div 24=1.67$.

以下表-3 亿示す央測值から計画に必要な基礎事項を知 ることができるから，これら所要の值を示すと表一5の ようになる。

つぎそ特定の駐車時間 $\beta$ 以下のものを除外した場合の 補正については, 今仮りに $\beta=5$ 分以下の駐車は計画に 入れないものとすると, この場合の観測もれの車は式 (15)（あるいは図一9）から求めて， $\alpha=\beta / T=1 / 2$ なる ことを考虑して,

$$
W_{0}^{\prime}=3.3 \%
$$

また 5 分以下の車で観測されているものは式 (17)（あ るいは図一10）から $3.8 \%$ となり，奏用的には，この值 
は観測もれのものと大体同じ割合となっているからっ一 応観測実台数 36 台が所要の台数であるとしてよいこと そなる。しかるときは 1 回観測資料中 $W_{0}^{\prime}$ 飞相当する ものは式 (18) で計算されるから，その台数について式 （16）の駐車時間を求め, 以下上飞述べたと同じ方法に よって所要の值を計算すればよい。

\section{7.むすび}

以上諸外国ならびそわが国で実施されてきた駐車実態 の調查方法について，比較検討を加兑てその得失を明ら かとし，駐車場の計画とあたって必要な基礎事項とその 意義を明確とするとともに, 駐車実態の調査方式として 1 種の断続的調查方法であるが, きわめて容易に実用に 供しうる方法を提案した。駐車現象はきわめて複雑で， その実態を把握するため調查には多大の経費と労力を必 要とするものであるが，ここに提案した方法によれば， 容易飞少数の人員で広範にわたる調査が可能となり，駐 車問題解決上益すとるころ大なるものがあると確信す る。

な招この調查方法に起因する観測もれの車, 駐車時間 の補正は, ここに述べた理論にしたがって容易に算出で きることを明らかにするととるに，従来もっとも事実に 則しているが手数のかかる方法として行なわれてきた連 続調査方法と比較し，こてに提案した調查方式による観 測值の精度, 誤差飞関する理論的根拠を与えることがで きた。これらの結果は駐車問題解決のための基礎的指針 を与えるためと有効に利用されるものと思う。

最後化本研究は文部省科学試験研究費飞上る研究の一 部であって, 京大米谷栄二教授・名工大渡辺新三教授・ 岐阜大加藤 晃助教授の方々ので指導で協力を戴いたこ とに対して深甚なる謝意を表するとともに, 京都・名古 屋両市飞扰ける駐車場整備計画飞当たって, 駐車実態を 把握するためと行なった調査, ならびに大阪市に颃いて 道路公団大阪支社が路外駐車場建設飞必要とした駐車状 況の調查等はいずれも主としてここに述べた調查方式に よったもので,この研究の完成実行に非常なで援助を賜 った名古屋市計画局 谷 重幸計画部長, 京都市都市計 画局森田長雄技術長, 道路公団大阪支社 清水正夫調查 課長を初め関係部局の方々飞対して心からの謝意を表す る次第である。

\section{参考文献および資料}

1) Shopping Centers Re-Studied, Urban Land Institute Technical Bulletin No. 30, Washington D.C. Feb. 1957, p. $39 \sim 51$

2) Traffic Engineering Guide, National Safety Council 425, N. Michigan Ave., Chicago 6, Ill., p. 22 27

3) Matson, Smith \& Hurd : Traffic Engineering, 1955, Chapter 17, Curb Parking Regulation, p. 278 293

4) Henry K. Evans: Traffic Engineering Handbook, 1950, Chapter X, Parking and Loading, p. 290 317

5) Burrage, R.H. \& Mogren, E.G. : Parking, The Eno Foundation for Highway Traffic Control, Saugatuck Connecticut, 1957

6) Ricker, E.R.: Traffic Design of Parking Garages, The Eno Foundation, 1957

7) Baker, G. \& Funaro, B. : Parking, Reinhold Publishing Corporation, N.Y., U.S.A. 1958

8) Zoning for Parking Facilities : Highway Research Board Bulletin No. 24, 1950

9）駐車場法（昭 32.5.16. 法律第 106 号 改正昭 37.4.16. 法律第 81 号)

10）京須 実：駐車場法について，新都市第 11 巻第 6 号（昭 32.6) p. $7 \sim 11$

11）駐車場法施行令（昭 32.12.13. 政令第 340 号 改正 昭 37.7.27. 政令第 310 号)

12）村山幸雄 : 駐車場法に伴う技術的基準の考え方，新都市 第11巻第 6 号 (昭 32.6 ) p. 12 19

13）日本道路協会編：道路手帳，技報堂（昭 32.10 .20 ) p. 124

14）小清水勇：パーキング・ロットの選定と設計，ぱあきん ぐ, 日本駐車協会 1958 年第 2 号 p. 2 6

15）並木昭夫：自動車駐車場について，第 4 回 日本道路会議 論文集 (昭 33.6) p. 779 782

16）新谷洋二：駐車場設計に関する一考察，第 4 回日本道路 会議論文集（昭 $33.6 ）$ p. 770 774

17）道路交通法（昭 35.6.25. 法律第 105 号，施行昭 35.12 . 20)

18）毛利正光：駐車現象の統計解析，土木学会 論文 集 第 66 号, 昭 35.1 .

19）毛利正光：交通流の分布に関する統計学的考察，都市計 画学会誌, 第 5 巻 4 号, 1956, No. 4 , p. $13 \sim 21$

20）毛利正光：駐車場計画に関する 基礎理論の研究，土木学 会論文集第 38 号, 昭. 31.10 , p. $47 \sim 53$

21）駐車場計画における車両の出入量強度の算定法と運営に 関する基礎的考察, 土木学会論文集 第 46 号, 昭.32.6. p. $41 \sim 51$

22）毛利正光 : 観光駐車場の 将来計画に関する研究，土木学 会論文集第 61 号, p. 54 62

23）毛利正光：同上, 土木学会諭文集第 62 号, p. 49 55

24）毛利正光: 駐車スペースの利用指数について, 第 5 回日 本道路会議論文集, 昭 35 年,

25）米谷栄二・毛利正光：路外駐車場の 経済的管理運営機構 について, 土木学会第 14 回年次学術講演会

(1964.3.25 • 受付) 